\title{
Actinaurispora siamensis gen. nov., sp. nov., a new member of the family Micromonosporaceae
}

\author{
Chitti Thawai, ${ }^{1,2}$ Somboon Tanasupawat, ${ }^{3}$ Khanit Suwanborirux $^{4,5}$ \\ and Takuji Kudo ${ }^{6}$
}

Correspondence

Chitti Thawai

ktchitti@kmitl.ac.th

\author{
${ }^{1}$ Department of Biology, Faculty of Science, King Mongkut's Institute of Technology Ladkrabang, \\ Bangkok 10520, Thailand \\ ${ }^{2}$ Microbial Resource Management Unit, Scientific Instrument Center, Faculty of Science, \\ King Mongkut's Institute of Technology Ladkrabang, Bangkok 10520, Thailand \\ ${ }^{3}$ Department of Microbiology, Faculty of Pharmaceutical Sciences, Chulalongkorn University, \\ Bangkok 10330, Thailand \\ ${ }^{4}$ Center for Bioactive Natural Products from Marine Organisms and Endophytic Fungi (BNPME), \\ Bangkok 10330, Thailand \\ ${ }^{5}$ Department of Pharmacognosy, Faculty of Pharmaceutical Sciences, Chulalongkorn University, \\ Bangkok 10330, Thailand \\ ${ }^{6}$ Japan Collection of Microorganisms, RIKEN BioResource Center, Wako, Saitama 351-0198, \\ Japan
}

Two actinomycete strains, $\mathrm{CM} 2-8^{\top}$ and $\mathrm{CM} 2-12$, were isolated from temperate peat swamp forest soil in Chiang Mai Province, Thailand. Their taxonomic positions were determined using a polyphasic approach. Chemotaxonomic characteristics of these strains coincided with those of the family Micromonosporaceae, i.e. cell wall chemotype II, $\mathrm{N}$-glycolyl type of muramic acid, and type II phospholipids. Phylogenetic analysis based on 16S rRNA gene sequence data also indicated that these strains fell within the family Micromonosporaceae and formed a distinct taxon in the Micromonosporaceae phylogenetic tree. On the basis of phylogenetic analysis,

characteristic patterns of 16S rRNA gene signature nucleotides and chemotaxonomic data, it is proposed that the novel isolates belong to a new genus, Actinaurispora gen. nov. The type species of the genus is proposed as Actinaurispora siamensis sp. nov., with strain $\mathrm{CM} 2-8^{\top}$ $\left(=\mathrm{JCM} 15677^{\top}=\mathrm{BCC} 34762^{\top}\right)$ as the type strain.
The family Micromonosporaceae was first described by Krasil'nikov (1938), and amended by Koch et al. (1996), Stackebrandt et al. (1997) and Zhi et al. (2009), who classified 17 genera [Actinocatenispora (Thawai et al., 2006), Actinoplanes (Couch, 1950), Asanoa (Lee \& Hah, 2002), Catellatospora (Asano \& Kawamoto, 1986), Catenuloplanes (Yokota et al., 1993), Couchioplanes (Tamura et al., 1994), Dactylosporangium (Thiemann et al., 1967), Longispora (Matsumoto et al., 2003), Micromonospora (Ørskov, 1923),

Abbreviation: DAP, diaminopimelic acid.

The GenBank/EMBL/DDBJ accession numbers for the $16 \mathrm{~S}$ rRNA gene sequences of strains $\mathrm{CM}_{2}-8^{\top}$ and $\mathrm{CM} 2-12$ are $\mathrm{AB} 454379$ and AB465341, respectively.

Phylogenetic trees based on almost complete 16S rRNA gene sequences constructed using the neighbour-joining, maximumparsimony and minimum-evolution methods and tables giving the fatty acid composition and 16S rRNA gene signature nucleotide positions of strains $C M 2-8^{\top}$ and $C M 2-12$ and related strains/species are available with the online version of this paper.
Pilimelia (Kane, 1966), Polymorphospora (Tamura et al., 2006), Planosporangium (Wiese et al., 2008), Pseudosporangium (Ara et al., 2008a), Salinispora (Maldonado et al., 2005), Spirilliplanes (Tamura et al., 1997), Verrucosispora (Rheims et al., 1998) and Virgisporangium (Tamura et al., 2001)] within this family on the basis of $16 \mathrm{~S}$ rRNA gene sequence analysis. Two actinomycete genera, Luedemannella (Ara \& Kudo, 2007a) and Krasilnikovia (Ara \& Kudo, 2007b), have since been described as additional members of the family. Recently, Catellatospora koreensis and Catellatospora tsunoense were transferred to the genera Catelliglobosispora (as Catelliglobosispora koreensis) and Hamadaea (as Hamadaea tsunoensis), respectively, based on 16S rRNA gene sequence analysis and chemotaxonomic data (Ara et al., 2008b).

During an investigation of the actinomycete diversity of soils in northern Thailand, two strains, CM2 $-8^{\mathrm{T}}$ and CM212, which showed chemotaxonomic characteristics that were typical of members of the family Micromonosporaceae 
but which represented a novel phylogenetic lineage, were isolated. In this report, these strains were characterized using a polyphasic approach and it is proposed that they be classified as representatives of a novel species in a new genus.

Strains CM2-8 ${ }^{\mathrm{T}}$ and CM2-12 were isolated from temperate peat swamp forest soil in Chiang Mai Province, Thailand. Samples were taken from the soil surface and kept at $4{ }^{\circ} \mathrm{C}$. The sampling and isolation methods have been described by Thawai et al. (2004) and pure cultures were kept at 4$10{ }^{\circ} \mathrm{C}$ on yeast extract-malt extract agar (ISP 2 medium) slants.

Strains CM2-8 ${ }^{\mathrm{T}}$ and CM2-12 were grown for 14 days at $30{ }^{\circ} \mathrm{C}$ on humic acid-vitamin agar and observed by light and scanning electron microscopy (model JSM-5410 LV; JEOL). Samples for scanning electron microscopy were prepared as described previously (Itoh et al., 1989).

Cultural, physiological and biochemical characteristics were examined by using several standard methods; cultural characteristics were tested using 21 day cultures grown at $30{ }^{\circ} \mathrm{C}$ on various media. The Jacal Colour Card L2200 (Japan Colour Research Institute) was used for determining colour designations and names. Decomposition of various compounds was examined using the basal medium recommended by Gordon et al. (1974). Temperature, $\mathrm{NaCl}$ and $\mathrm{pH}$ tolerance were determined on ISP 2 medium. Carbon source utilization was tested using ISP 9 medium (Shirling \& Gottlieb, 1966) supplemented with a final concentration of $1 \%$ of the tested carbon sources and $0.05 \%$ Casamino acids. Gelatin liquefaction, peptonization of milk, nitrate reduction and starch hydrolysis were determined by cultivation on various media as described by Arai (1975) and Williams \& Cross (1971). Melanin and hydrogen sulphide production were examined on tyrosine agar and peptone iron agar slants supplemented with $0.1 \%$ $(\mathrm{w} / \mathrm{v})$ yeast extract.

Freeze-dried cells used for chemotaxonomic analyses were obtained from cultures grown in yeast extract-malt extract broth (ISP 2 broth) on a rotary shaker at $30{ }^{\circ} \mathrm{C}$ for 5 days. Cell wall peptidoglycan was prepared and hydrolysed according to Kawamoto et al. (1981) and the amino acid composition was analysed with an automatic amino acid analyser. The cell wall diaminopimelic acid (DAP) isomers were determined by the method of Staneck \& Roberts (1974). The acyl group of the muramic acid in the peptidoglycan was determined by the method of Uchida \& Aida (1984). Reducing sugars from whole-cell hydrolysates were analysed by the HPLC method of Mikami \& Ishida (1983). Cell phospholipids were extracted and analysed by the method of Minnikin et al. (1984). Fatty acid methyl ester analysis was performed by GLC according to the instructions of the Microbial Identification System (MIDI) (Sasser, 1990; Kämpfer \& Kroppenstedt, 1996). The presence of mycolic acids was investigated by using the method of Minnikin et al. (1975). Isoprenoid quinones were extracted by the method of Collins et al.
(1977) and analysed by HPLC equipped with a Cosmosil $5 \mathrm{C}_{18}$ column $(4.6 \times 150 \mathrm{~mm}$; Nacalai Tesque). The elution solvent was a mixture of methanol and 2-propanol $(2: 1, \mathrm{v} / \mathrm{v})$.

Chromosomal DNA was isolated from cells grown in ISP 2 broth according to the method of Tamaoka (1994). The DNA G $+\mathrm{C}$ content was determined using the HPLC method of Tamaoka \& Komagata (1984). An equimolar mixture of nucleotides for analysis of DNA base composition (Yamasa Shoyu) was digested by bacterial alkaline phosphatase into nucleosides and used as the quantitative standard. DNA-DNA hybridization was conducted in microdilution plates, as reported by Ezaki et al. (1989). Hybridization was carried out at $55{ }^{\circ} \mathrm{C}$ for $2 \mathrm{~h}$. DNA-DNA relatedness (\%) was determined by using the colorimetric method (Verlander, 1992).

Genomic DNA extraction, PCR-mediated amplification of the 16S rRNA gene and sequencing of PCR products were carried out as described by Nakajima et al. (1999). The $16 \mathrm{~S}$ rRNA gene sequence was multiply aligned with selected sequences obtained from the GenBank/EMBL/DDBJ databases using CLUSTAL $\mathrm{W}$ version 1.81 (Thompson et al., 1994). Alignment was verified manually and adjusted prior to the construction of a phylogenetic tree. The phylogenetic tree was constructed by using the neighbour-joining (Saitou \& Nei, 1987), maximum-parsimony (Kluge \& Farris, 1969) and minimum-evolution (Felsenstein, 1997) methods in the MEGA program version 2.1. Confidence values of branches of the phylogenetic tree were determined using bootstrap analyses (Felsenstein, 1985) based on 1000 resamplings. Sequence similarity values between closely related strains were determined using the EzTAXON server (Chun et al., 2007).

Strains CM2-8 ${ }^{\mathrm{T}}$ and CM2-12 produced well-developed and branched substrate hyphae on ISP 2 agar, but no aerial hyphae. Spores were borne singly on the substrate hyphae and were $0.4-0.6 \mathrm{~mm}$ in diameter (Fig. 1). Spores had a rough surface and were non-motile. Colonies of strains CM2-8 ${ }^{\mathrm{T}}$ and CM2-12 were strong reddish orange in colour and did not darken after sporulation; soluble pigments were not produced on most of the media tested, with the exception of a pale-yellow pigment on ISP 2 agar. Physiological and biochemical characteristics of the strains are presented in the species description.

Cell-wall hydrolysates of the two novel isolates contained glutamic acid, glycine, alanine and meso-DAP, indicating that these strains have wall chemotype II (described by Lechevalier \& Lechevalier, 1970); the peptidoglycan was of type A1 $\gamma$ (described by Schleifer \& Kandler, 1972). The acyl moiety of murein contained glycolyl residues. The isolates contained glucose, galactose, xylose and mannose as wholecell sugars, but not arabinose or ribose. The characteristic phospholipids were diphosphatidylglycerol, phosphatidylinositol, phosphatidylinositol mannosides and phosphatidylethanolamine; phosphatidylcholine was not present. 


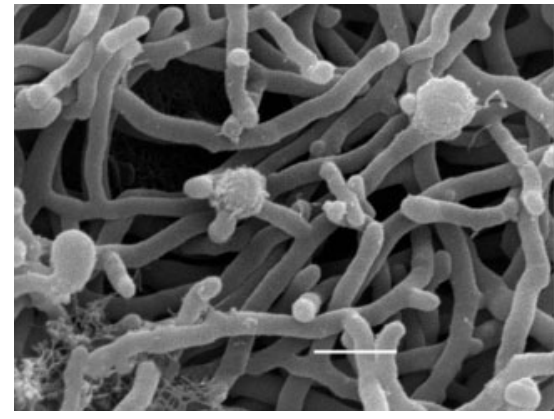

Fig. 1. Scanning electron micrograph of strain $C M 2-8^{\top}$. Bar, $1 \mu \mathrm{m}$.

This pattern corresponds to phospholipid type II of Lechevalier et al. (1977). The cellular fatty acid compositions are shown in Supplementary Table S1, available in IJSEM Online. The major fatty acids of CM2-8 ${ }^{\mathrm{T}}$ and CM212 were iso- $\mathrm{C}_{15: 0}$, iso- $\mathrm{C}_{16: 0}$, anteiso- $\mathrm{C}_{17: 0}$, anteiso- $\mathrm{C}_{15: 0}$ and iso- $\mathrm{C}_{17: 0} ; 10$-methyl- $\mathrm{C}_{17: 0}$ was also found. This pattern corresponds to fatty acid type $3 \mathrm{~b}$ described by Kroppenstedt (1985). Mycolic acids were not detected. The predominant menaquinones found in the isolates were MK-9 $\left(\mathrm{H}_{6}\right) \quad(41.7 \%)$, MK-10 $\left(\mathrm{H}_{6}\right) \quad(15.9 \%), \quad$ MK-9 $\left(\mathrm{H}_{8}\right)$ $(9.4 \%)$ and $\mathrm{MK}-10\left(\mathrm{H}_{8}\right)(5.4 \%)$; small amounts of MK-9 $\left(\mathrm{H}_{4}\right)(1.3 \%)$, MK-10 $\left(\mathrm{H}_{4}\right)(0.7 \%)$ and MK-9 $\left(\mathrm{H}_{2}\right)$ $(0.5 \%)$ were also present. The DNA G+C contents for strains CM2-8 ${ }^{\mathrm{T}}$ and CM2-12 were 72.6 and $72.2 \mathrm{~mol} \%$, respectively.

These chemotaxonomic characteristics, in particular the cell-wall type (type II), the muramic acid acyl type $(\mathrm{N}$ glycolyl), the absence of mycolic acids and the phospholipid type (type II), suggest that strains $\mathrm{CM} 2-8^{\mathrm{T}}$ and CM212 are members of the family Micromonosporaceae.

Almost complete $16 \mathrm{~S}$ rRNA gene sequences of isolates CM2$8^{\mathrm{T}}$ (1446 nt) and CM2-12 (1450 nt) were compared against 16S rRNA gene sequences of all members of the genus Micromonospora and all members of the family Micromonosporaceae. Phylogenetic analysis based on this large dataset revealed that the novel isolates belonged to a cluster of the family Micromonosporaceae (see Supplementary Figs S1, S2 and S3, available in IJSEM Online). When the sequences of $\mathrm{CM} 2-8^{\mathrm{T}}$ and $\mathrm{CM} 2-12$ were compared with selected $16 \mathrm{~S}$ rRNA gene sequences of all genera in the family Micromonosporaceae and the 16S rRNA gene sequence of Streptomyces ambofaciens (used as an outgroup), it was observed that they represented a new phyletic line that was different from all described genera in this family (Fig. 2). The highest levels of similarity were with Micromonospora eburnea JCM $12345^{\mathrm{T}}$ (97.9\%), Micromonospora auratinigra JCM $12357^{\mathrm{T}}(97.5 \%)$, Salinispora arenicola $\mathrm{CNH}-643^{\mathrm{T}}$ (97.4\%), Micromonospora nigra DSM $43818^{\mathrm{T}}(97.3 \%)$ and Salinispora tropica CNB- $440^{\mathrm{T}}(97.3 \%)$. Although the two novel isolates showed highest levels of 16S rRNA gene sequence similarity to members of the genus
Micromonospora, phylogenetic analysis indicated that the isolates did not cluster within the genus Micromonospora but were related to members of the genus Salinispora. Signature nucleotides of the 16S rRNA gene sequence of the isolates were shared in all but one position (840: 846 according to the Escherichia coli numbering scheme) with genera of the family Micromonosporaceae (Zhi et al., 2009). However, signature nucleotides of the novel isolates differed from those of their closest neighbours, members of the genera Micromonospora and Salinispora, in several positions (Supplementary Table S2, available in IJSEM Online) and clearly differentiate the novel strains from both of these genera. The gene sequence similarity between isolates CM2-8 ${ }^{\mathrm{T}}$ and CM2-12 was $100 \%$. The DNA-DNA relatedness value between the two novel isolates was $88.9 \pm 0.8 \%$.

Members of the two genera Micromonospora and Salinispora seem to be most closely related to isolates $\mathrm{CM} 2-8^{\mathrm{T}}$ and CM2-12. Members of the genus Salinispora require seawater for growth. The initial colour of colonies is orange to deep orange and can become darkened after sporulation. They have arabinose, galactose and xylose as diagnostic sugars in whole-cell hydrolysates, MK- $9\left(\mathrm{H}_{4}\right)$ as the major menaquinone component and fatty acid type $3 \mathrm{a}$. Members of the genus Micromonospora have arabinose and xylose as the major sugars, and MK-10 $\left(\mathrm{H}_{4,6}\right)$ and MK$9\left(\mathrm{H}_{4,6}\right)$ as the predominant menaquinone components. All members of this genus exhibit yellowish white to orange brown substrate mycelia and turn greyish black to black after sporulation. Isolates $\mathrm{CM} 2-8^{\mathrm{T}}$ and $\mathrm{CM} 2-12$ can be clearly distinguished from members of these two genera in terms of colony colour, physiological characteristics (i.e. the requirement of seawater for growth), characteristic whole-cell sugars, predominant menaquinones and fatty acid composition.

These data suggest that the novel isolates do not belong to any known genera of the family Micromonosporaceae. Differential characteristics for the isolates and members of related genera in the family Micromonosporaceae are shown in Table 1.

On the basis of phenotypic, chemotaxonomic and genotypic data, isolates CM2-8 ${ }^{\mathrm{T}}$ and CM2-12 are readily distinguishable from the members of all established genera in the family Micromonosporaceae. Therefore, it is proposed that isolates $\mathrm{CM} 2-8^{\mathrm{T}}$ and $\mathrm{CM} 2-12$ should be classified as representatives of a novel species in a new genus, for which the name Actinaurispora siamensis gen. nov., sp. nov. is proposed.

\section{Description of Actinaurispora gen. nov.}

Actinaurispora [Ac.tin.au.ri.spo'ra. Gr. n. actis -inos ray; L. n. aurum gold, the colour of gold; N.L. fem. n. spora (from Gr. n. spora seed) a spore; N.L. fem. n. Actinaurispora ray (fungus) producing orange spores].

Gram-positive, non-acid-fast and aerobic. Form extensively branched substrate hyphae. Colonies are strong 


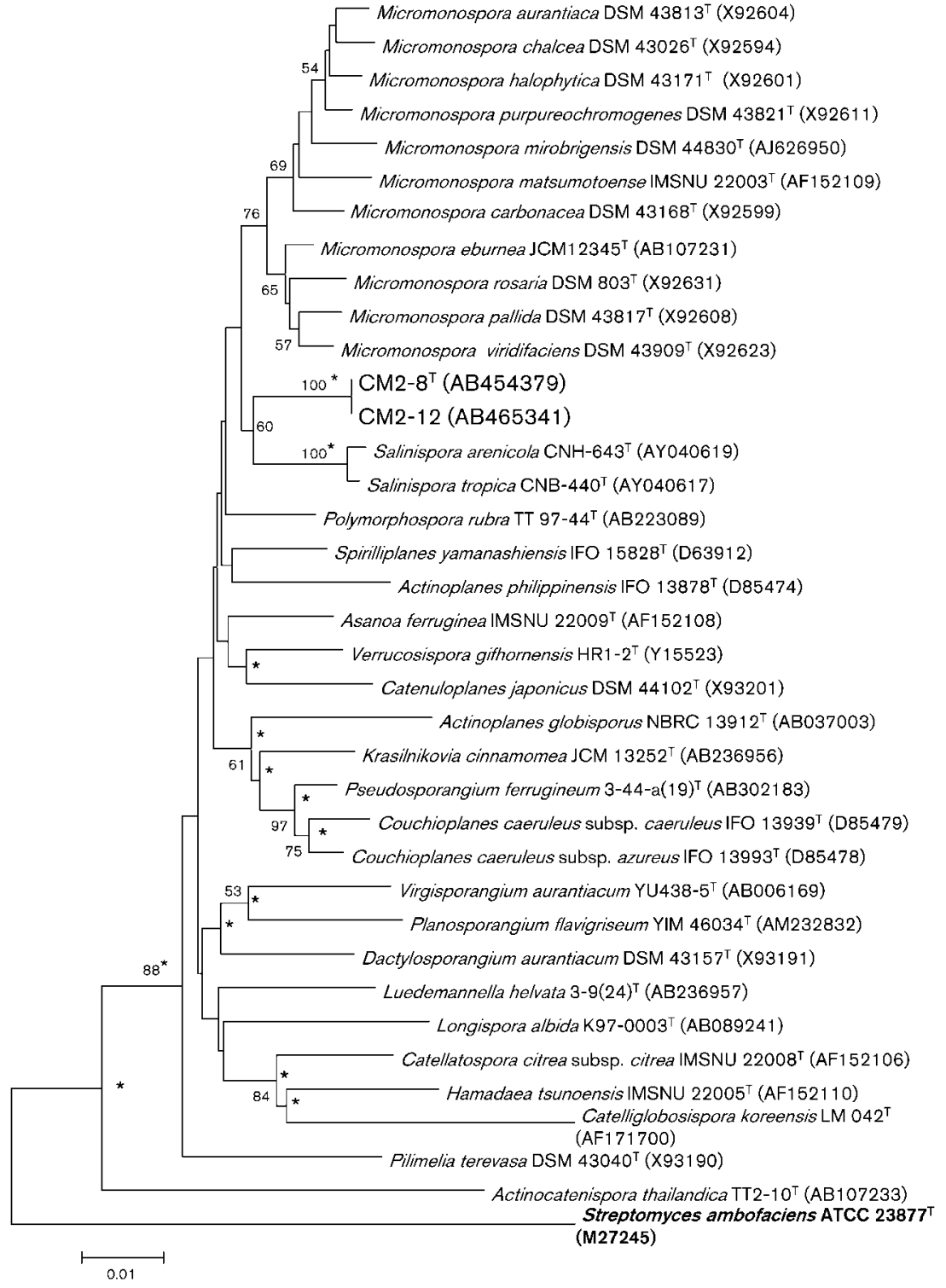

Fig. 2. Neighbour-joining tree (Saitou \& Nei, 1987) based on almost complete 16S rRNA gene sequences showing the relationships between $\mathrm{CM} 2-8^{\top}, \mathrm{CM} 2-12$, and strains of all type species of recognized representative members of the family Micromonosporaceae. The 16S rRNA gene sequence of Streptomyces ambofaciens ATCC $23877^{\top}$ was used as an outgroup. Asterisks indicate branches of the tree that were also found using the maximum-parsimony (Kluge \& Farris, 1969) and minimum-evolution (Felsenstein, 1997) methods. Bootstrap values (\%) of 1000 replicates are indicated at branch-points; only values $>50 \%$ are shown. Bar, 0.01 substitutions per nucleotide position. reddish orange in ISP 2 medium and do not darken after sporulation. Single spores with rough-surfaced spores (0.4$0.6 \mu \mathrm{m}$ in diameter) are formed on substrate hyphae. Aerial mycelium is absent. Spores are non-motile. A paleyellow pigment is produced in ISP 2. Cell wall contains glutamic acid, glycine, alanine and meso-DAP. The $N$-acyl group of the cell wall muramic acid is glycolyl. Glucose, xylose, mannose and galactose are detected as whole-cell sugars. Contains phosphatidylethanolamine, diphosphatidylglycerol, phosphatidylinositol and phosphatidylinositol mannosides as cellular phospholipids (phospholipid pattern type II). Predominant menaquinones are MK-9 $\left(\mathrm{H}_{6}\right)$, MK-10 $\left(\mathrm{H}_{6}\right)$, MK-9 $\left(\mathrm{H}_{8}\right)$ and MK-10 $\left(\mathrm{H}_{8}\right)$; minor components are MK-9 $\left(\mathrm{H}_{4}\right), \mathrm{MK}-10\left(\mathrm{H}_{4}\right)$ and $\mathrm{MK}-9\left(\mathrm{H}_{2}\right)$. The major fatty acids are iso- $\mathrm{C}_{15: 0}$, iso- $\mathrm{C}_{16: 0}$, anteiso- $\mathrm{C}_{17: 0}$, anteiso- $\mathrm{C}_{15: 0}$ and iso- $\mathrm{C}_{17: 0} ; 10$-methyl- $\mathrm{C}_{17: 0}$ is also found. Mycolic acids are not detected. Isolated from soil. The type species is Actinaurispora siamensis.

\section{Description of Actinaurispora siamensis sp. nov.}

Actinaurispora siamensis (si.am.en'sis. N.L. fem. adj. siamensis pertaining to Siam, the old name for Thailand, the country of origin of the soil from which the type strain was isolated).

Morphological, chemotaxonomic and general characteristics are as described for the genus. Utilizes D-glucose, Lrhamnose, melibiose, lactose, D-galactose, cellobiose, Dfructose and D-xylose, but not D-mannitol, D-ribose, raffinose, glycerol, salicin or L-arabinose. Weakly positive for peptonization of milk and gelatin liquefaction. Negative for hydrolysis of starch, formation of melanin, $\mathrm{H}_{2} \mathrm{~S}$ production and reduction of nitrate. The optimal temperature for growth is $25-30{ }^{\circ} \mathrm{C}$. No growth occurs above $40{ }^{\circ} \mathrm{C}$. Minimum $\mathrm{pH}$ tolerated is 5 . Maximum $\mathrm{NaCl}$ concentration for growth is $1.5 \%$. Does not require seawater for growth. 
Table 1. Differential characteristics of the genus Actinaurispora and related genera

Taxa: 1, Actinaurispora gen. nov.; 2, Actinocatenispora; 3, Actinoplanes; 4, Asanoa; 5, Catellatospora; 6, Catenuloplanes; 7, Couchioplanes; 8, Dactylosporangium; 9, Longispora; 10, Luedemannella; 11, Micromonospora; 12, Pilimelia; 13, Polymorphospora; 14, Salinispora; 15, Spirilliplanes; 16, Verrucosispora; 17, Virgisporangium; 18, Planosporangium; 19, Pseudosporangium; 20, Krasilnikovia; 21, Hamadaea; 22, Catelliglobosispora. Data are from Thawai et al. (2006), Couch (1950), Goodfellow et al. (1990), Lee et al. (2000), Lee \& Hah (2002), Asano \& Kawamoto (1986), Ara \& Kudo (2006, 2007a, b), Yokota et al. (1993), Kudo et al. (1999), Tamura et al. (1994, 1997, 2001, 2006), Thiemann et al. (1967), Matsumoto et al. (2003), Ørskov (1923), Kane (1966), Maldonado et al. (2005), Rheims et al. (1998), Stackebrandt \& Kroppenstedt (1987), Vobis (1989), Wiese et al. (2008) and Ara et al. (2008a, b). +, Present; -, absent; ND, not determined. Ara, Arabinose; Gal, galactose; Rham, rhamnose; Rib, ribose; Man, mannose; Xyl, xylose.

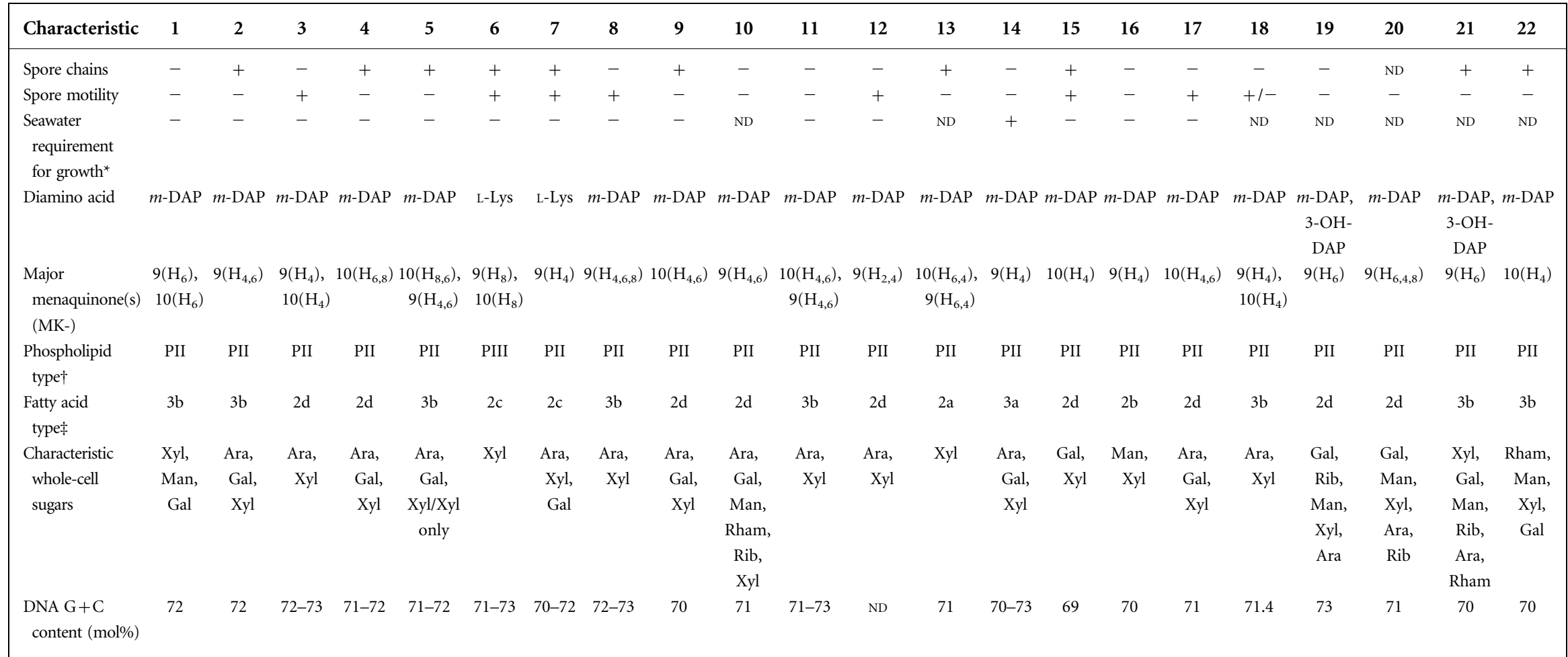

${ }^{*}$ Data from Maldonado et al. (2005).

$\dagger$ According to the classification of Lechevalier et al. (1977).

\$According to the classification of Kroppenstedt (1985). 
The type strain is CM2-8 $8^{\mathrm{T}}\left(=\mathrm{JCM} 15677^{\mathrm{T}}=\mathrm{BCC} 34762^{\mathrm{T}}\right)$, isolated from temperate peat swamp forest soil in Chiang Mai Province, Thailand. The DNA G $+\mathrm{C}$ content of the type strain is $72.6 \mathrm{~mol} \%$.

\section{Acknowledgements}

The research grant from the office of the National Research Council of Thailand (NRCT) to C.T. is gratefully acknowledged. We are grateful to the Center of Bioactive Natural Products from Marine Organisms and Endophytic Fungi (BNPME), the Faculty of Pharmaceutical Sciences, Chulalongkorn University and the Microbial Resource Management Unit, Scientific Instrument Center, Faculty of Science, King Mongkut's Institute of Technology Ladkrabang for supporting this project.

\section{References}

Ara, I. \& Kudo, T. (2006). Three novel species of the genus Catellatospora, Catellatospora chokoriensis sp. nov., Catellatospora coxensis sp. nov. and Catellatospora bangladeshensis sp. nov., and transfer of Catellatospora citrea subsp. methionotrophica Asano and Kawamoto 1988 to Catellatospora methionotrophica sp. nov., comb. nov. Int J Syst Evol Microbiol 56, 393-400.

Ara, I. \& Kudo, T. (2007a). Luedemannella gen. nov., a new member of the family Micromonosporaceae and description of Luedemannella helvata sp. nov. and Luedemannella flava sp. nov. J Gen Appl Microbiol 53, 39-51.

Ara, I. \& Kudo, T. (2007b). Krasilnikovia gen. nov., a new member of the family Micromonosporaceae and description of Krasilnikovia cinnamonea sp. nov. Actinomycetologica 21, 1-10.

Ara, I., Matsumoto, A., Bakir, M. A., Kudo, T., Ōmura, S. \& Takahashi, Y. (2008a). Pseudosporangium ferrugineum gen. nov., sp. nov., a new member of the family Micromonosporaceae. Int J Syst Evol Microbiol 58, 1644-1652.

Ara, I., Bakir, M. A. \& Kudo, T. (2008b). Transfer of Catellatospora koreensis Lee et al. 2000 as Catelliglobosispora koreensis gen. nov. comb. nov. and Catellatospora tsunoense Asano et al. 1989 as Hamadaea tsunoensis gen. nov., comb. nov., and emended description of the genus Catellatospora Asano and Kawamoto 1986 emend. Lee and Hah 2002. Int J Syst Evol Microbiol 58, 1950-1960.

Arai, T. (1975). Culture Media for Actinomycetes. Tokyo: The Society for Actinomycetes Japan.

Asano, K. \& Kawamoto, I. (1986). Catellatospora, a new genus of the Actinomycetales. Int J Syst Bacteriol 36, 512-517.

Chun, J., Lee, J.-H., Jung, Y., Kim, M., Kim, S., Kim, B. K. \& Lim, Y. W. (2007). EzTaxon: a web-based tool for the identification of prokaryotes based on $16 \mathrm{~S}$ ribosomal RNA gene sequences. Int J Syst Evol Microbiol 57, 2259-2261.

Collins, M. D., Pirouz, T., Goodfellow, M. \& Minnikin, D. E. (1977). Distribution of menaquinones in actinomycetes and corynebacteria. J Gen Microbiol 100, 221-230.

Couch, J. N. (1950). Actinoplanes. A new genus of the Actinomycetales. J Elisha Mitchell Sci Soc 66, 87-92.

Ezaki, T., Hashimoto, Y. \& Yabuuchi, E. (1989). Fluorometric deoxyribonucleic acid-deoxyribonucleic acid hybridization in microdilution wells as an alternative to membrane filter hybridization in which radioisotopes are used to determine genetic relatedness among bacterial strains. Int J Syst Bacteriol 39, 224-229.

Felsenstein, J. (1985). Confidence limits on phylogenies: an approach using the bootstrap. Evolution 39, 783-791.
Felsenstein, J. (1997). An alternating least-squares approach to inferring phylogenies from pairwise distances. Syst Biol 46, 101-111.

Goodfellow, M., Stanton, L. J., Simpson, K. E. \& Minnikin, D. E. (1990). Numerical and chemical classification of Actinoplanes and some related actinomycetes. J Gen Microbiol 136, 19-36.

Gordon, R. E., Barnett, D. A., Handerhan, J. E. \& Pang, C. H.-N. (1974). Nocardia coeliaca, Nocardia autotrophica, and the nocardin strain. Int J Syst Bacteriol 24, 54-63.

Itoh, T., Kudo, T., Parenti, F. \& Seino, A. (1989). Amended description of the genus Kineosporia, based on chemotaxonomic and morphological studies. Int J Syst Bacteriol 39, 168-173.

Kämpfer, P. \& Kroppenstedt, R. M. (1996). Numerical analysis of fatty acid patterns of coryneform bacteria and related taxa. Can J Microbiol 42, 989-1005.

Kane, W. D. (1966). A new genus of the Actinoplanaceae, Pilimelia, with a description of two species, Pilimelia terevasa and Pilimelia anulata. J Elisha Mitchell Sci Soc 82, 220-230.

Kawamoto, I., Oka, T. \& Nara, T. (1981). Cell wall composition of Micromonospora olivoasterospora, Micromonospora sagamiensis, and related organisms. J Bacteriol 146, 527-534.

Kluge, A. G. \& Farris, J. S. (1969). Quantitative phyletics and the evolution of anurans. Syst Zool 18, 1-32.

Koch, C., Kroppenstedt, R. M., Rainey, F. A. \& Stackebrandt, E. (1996). 16S ribosomal DNA analysis of the genera Micromonospora, Actinoplanes, Catellatospora, Catenuloplanes, Couchioplanes, Dactylosporangium, and Pilimelia and emendation of the family Micromonosporaceae. Int J Syst Bacteriol 46, 765-768.

Krasil'nikov, N. A. (1938). Ray Fungi and Related Organisms Actinomycetales. Moscow: Akademii Nauk SSSR.

Kroppenstedt, R. M. (1985). Fatty acid and menaquinone analysis of actinomycetes and related organisms. In Chemical Methods in Bacterial Systematics (Society for Applied Bacteriology Technical Series vol. 20), pp. 173-199. Edited by M. Goodfellow \& D. E. Minnikin. New York: Academic Press

Kudo, T., Nakajima, Y. \& Suzuki, K. (1999). Catenuloplanes crispus (Petrolini et al. 1993) comb. nov.: incorporation of the genus Planopolyspora Petrolini 1993 into the genus Catenuloplanes Yokota et al. 1993 with an amended description of the genus Catenuloplanes. Int J Syst Bacteriol 49, 1853-1860.

Lechevalier, M. P. \& Lechevalier, H. A. (1970). Chemical composition as a criterion in the classification of aerobic actinomycetes. Int $J$ Syst Bacteriol 20, 435-443.

Lechevalier, M. P., De Bièvre, C. \& Lechevalier, H. A. (1977). Chemotaxonomy of aerobic actinomycetes: phospholipid composition. Biochem Syst Ecol 5, 249-260.

Lee, S. D. \& Hah, Y. C. (2002). Proposal to transfer Catellatospora ferruginea and 'Catellatospora ishikariense' to Asanoa gen. nov. as Asanoa ferruginea comb. nov and Asanoa ishikariensis sp. nov., with emended description of the genus Catellatospora. Int J Syst Evol Microbiol 52, 967-972.

Lee, S. D., Kang, S. O. \& Hah, Y. C. (2000). Catellatospora koreensis sp. nov., a novel actinomycete isolated from a gold-mine cave. Int J Syst Evol Microbiol 50, 1103-1111.

Maldonado, L. A., Fenical, W., Jensen, P. R., Kauffman, C. A., Mincer, T. J., Ward, A. C., Bull, A. T. \& Goodfellow, M. (2005). Salinispora arenicola gen. nov., sp. nov. and Salinispora tropica sp. nov., obligate marine actinomycetes belonging to the family Micromonosporaceae. Int J Syst Evol Microbiol 55, 1759-1766.

Matsumoto, A., Takahashi, Y., Shinose, M., Seino, A., Iwai, Y. \& Omura, S. (2003). Longispora albida gen. nov., sp. nov., a novel genus of the family Micromonosporaceae. Int J Syst Evol Microbiol 53, 1553-1559. 
Mikami, H. \& Ishida, Y. (1983). Post-column fluorometric detection of reducing sugars in high-performance liquid chromatography using arginine. Bunseki Kagaku 32, E207-E210.

Minnikin, D. E., Alshamaony, L. \& Goodfellow, M. (1975). Differentiation of Mycobacterium, Nocardia, and related taxa by thin-layer chromatographic analysis of whole-organism methanolysates. J Gen Microbiol 88, 200-204.

Minnikin, D. E., O’Donnell, A. G., Goodfellow, M., Alderson, G., Athalye, M., Schaal, A. \& Parlett, J. H. (1984). An integrated procedure for the extraction of bacterial isoprenoid quinones and polar lipids. J Microbiol Methods 2, 233-241.

Nakajima, Y., Kitpreechavanich, V., Suzuki, K. \& Kudo, T. (1999). Microbispora corallina sp. nov., a new species of the genus Microbispora isolated from Thai soil. Int J Syst Bacteriol 49, 1761-1767.

Orskov, J. (1923). Investigations into the Morphology of the Ray Fungi. Copenhagen: Levin \& Munksgaard.

Rheims, H., Schumann, P., Rohde, M. \& Stackebrandt, E. (1998). Verrucosispora gifhornensis gen. nov., sp. nov., a new member of the actinobacterial family Micromonosporaceae. Int J Syst Bacteriol 48, 1119-1127.

Saitou, N. \& Nei, M. (1987). The neighbor-joining method: a new method for reconstructing phylogenetic trees. Mol Biol Evol 4, 406425.

Sasser, M. (1990). Identification of bacteria by gas chromatography of cellular fatty acids, MIDI Technical Note 101. Newark, DE: MIDI Inc.

Schleifer, K. H. \& Kandler, O. (1972). Peptidoglycan types of bacterial cell walls and their taxonomic implications. Bacteriol Rev 36, 407-477.

Shirling, E. B. \& Gottlieb, D. (1966). Methods for characterization of Streptomyces species. Int J Syst Bacteriol 16, 313-340.

Stackebrandt, E. \& Kroppenstedt, R. M. (1987). Union of the genera Actinoplanes Couch, Ampullariella Couch, and Amorphosporangium Couch in a redefined genus Actinoplanes. Syst Appl Microbiol 9, 110114.

Stackebrandt, E., Rainey, F. A. \& Ward-Rainey, N. L. (1997). Proposal for a new hierarchic classification system, Actinobacteria classis nov. Int J Syst Bacteriol 47, 479-491.

Staneck, J. L. \& Roberts, G. D. (1974). Simplified approach to identification of aerobic actinomycetes by thin-layer chromatography. Appl Microbiol 28, 226-231.

Tamaoka, J. (1994). Determination of DNA base composition. In Chemical Methods in Prokaryotic Systematics, pp. 463-470. Edited by M. Goodfellow \& A. G. O'Donnell. Chichester: Wiley.

Tamaoka, J. \& Komagata, K. (1984). Determination of DNA base composition by reversed-phase high-performance liquid chromatography. FEMS Microbiol Lett 25, 125-128.

Tamura, T., Nakagaito, Y., Nishii, T., Hasegawa, T., Stackebrandt, E. \& Yokota, A. (1994). A new genus of the order Actinomycetales, Couchioplanes gen. nov., with descriptions of Couchioplanes caeruleus (Horan and Brodsky 1986) comb. nov. and Couchioplanes caeruleus subsp. azureus subsp. nov. Int J Syst Bacteriol 44, 193-203.
Tamura, T., Hayakawa, M. \& Hatano, K. (1997). A new genus of the order Actinomycetales, Spirilliplanes gen. nov., with description of Spirilliplanes yamanashiensis sp. nov. Int J Syst Bacteriol 47, 97102.

Tamura, T., Hayakawa, M. \& Hatano, K. (2001). A new genus of the order Actinomycetales, Virgosporangium gen. nov., with descriptions of Virgosporangium ochraceum sp. nov. and Virgosporangium aurantiacum sp. nov. Int J Syst Evol Microbiol 51, 1809-1816.

Tamura, T., Hatano, K. \& Suzuki, K. (2006). A new genus of the order Actinomycetales, Polymorphospora gen. nov., with description of Polymorphospora rubra sp. nov. Int J Syst Evol Microbiol 56, 1959 1964.

Thawai, C., Tanasupawat, S., Itoh, T., Suwanborirux, K. \& Kudo, T. (2004). Micromonospora aurantionigra sp. nov., isolated from a peat swamp forest in Thailand. Actinomycetologica 18, 8-14.

Thawai, C., Tanasupawat, S., Itoh, T. \& Kudo, T. (2006). Actinocatenispora thailandica gen. nov., sp. nov., a new member of the family Micromonosporaceae. Int J Syst Evol Microbiol 56, 17891794.

Thiemann, J. E., Pagani, H. \& Beretta, G. (1967). A new genus of the Actinoplanaceae: Dactylosporangium, gen. nov. Arch Mikrobiol 58, 4252.

Thompson, J. D., Higgins, D. G. \& Gibson, T. J. (1994). CLUSTAL W: improving the sensitivity of progressive multiple sequence alignment through sequence weighting, position-specific gap penalties and weight matrix choice. Nucleic Acids Res 22, 4673-4680.

Uchida, K. \& Aida, K. (1984). An improved method for the glycolate test for simple identification of acyl type of bacterial cell walls. J Gen Appl Microbiol 30, 131-134.

Verlander, C. P. (1992). Detection of horseradish peroxidase by colorimetry. In Nonisotopic DNA Probe Techniques, pp. 185-201. Edited by L. J. Kricka. New York: Academic Press.

Vobis, G. (1989). Actinoplanetes. In Bergey's Manual of Systematic Bacteriology, vol. 4, pp. 2418-2450. Edited by S. T. Williams, M. E. Sharpe \& J. G. Holt. Baltimore: Williams \& Wilkins.

Wiese, J., Jiang, Y., Tang, S.-K., Thiel, V., Schmaljohann, R., Xu, L.-H., Jiang, C.-L. \& Imhoff, J. F. (2008). A new member of the family Micromonosporaceae, Planosporangium flavigriseum gen. nov., sp. nov. Int J Syst Evol Microbiol 58, 1324-1331.

Williams, S. T. \& Cross, T. (1971). Actinomycetes. In Methods in Microbiology, vol. 4, pp. 295-334. Edited by C. Booth. London: Academic Press.

Yokota, A., Tamura, T., Hasegawa, T. \& Huang, L. H. (1993). Catenuloplanes japonicus gen. nov., sp. nov., nom. rev., a new genus of the order Actinomycetales. Int J Syst Bacteriol 43, 805-812.

Zhi, X. Y., Li, W. J. \& Stackebrandt, E. (2009). An update of the structure and 16S rRNA gene sequence-based definition of higher ranks of the class Actinobacteria, with the proposal of two new suborders and four new families and emended descriptions of the existing higher taxa. Int J Syst Evol Microbiol 59, 589-608. 